\section{Márcia Arán'}

Carlos Augusto Peixoto Júnior"

\section{Vulnerability and bare life: bioethics and biopolitics today}

Instituto de Medicina Social. Universidade do Estado do Rio de Janeiro. Rio de Janeiro, RJ, Brasil

" Programa de Pós-graduação em Psicologia Clínica. Pontifícia Universidade Católica do Rio de Janeiro. Rio de Janeiro, RJ, Brasil

\footnotetext{
Correspondence:

Márcia Arán

Instituto de Medicina Social $\neg-$ UERJ

R. São Francisco Xavier, 524

Pavilhão João Lyra Filho, $7^{\circ}$ andar

Blocos D e E - Maracanã

20550-900 Rio de Janeiro, RJ, Brasil

E-mail: marciaaran@terra.com.br
}

\begin{abstract}
The study had the objective of analyzing the notion of vulnerability that is used by bioethics to debate research involving human beings today, from reflections on biopolitics in contemporary culture. For this, the starting point was Giorgio Agamben's reading of Foucault's model of power (Sovereignty and Biopolitics), with the aim of subsequently analyzing the notion of bare life: "life without any value". If the devices of power in modern democracies conjoin biopolitical strategies with the emergence of the strength of sovereign power that transforms life into bare life, in fact bioethics must be an instrument for protecting people who have become vulnerable. Nevertheless, beyond the territory of the rule of law, bioethics must also penetrate the undifferentiated zones where sovereignty and techniques become mixed, disrespecting the frontiers of biopolitics and questioning the condition of vulnerability itself.
\end{abstract}

KEY WORDS: Bioethics. Vulnerability. Health vulnerability. Value of life. Health research policy. Ethics, research. Human experimentation, ethics.

\section{INTRODUCTION}

Beginning in the middle of the sixteenth century, the sciences - notably the physical-mathematical sciences under Galileo and Newton, but also biological sciences and anatomy under André Vesalius - forsook the more passive or contemplative attitudes towards nature that were grounded in essentially metaphysical perspectives. In an aurora of modernity, they adopted a more active stance in which the experimental method, with its requirements for observation and verification of hypotheses played a fundamental role. Modern science has broken down the separation between episteme (theoretical knowledge) and techne (applied knowledge), thereby integrating scientific and technical discourse. This has meant that practical problems within the technical sphere lead to scientific developments, and also that theoretical hypotheses are tested out in practice through their technical application. Under these conditions, development of the experimental method has necessarily implied the transformation of objects under investigation into experimental subjects. It happens that, from the animal guinea pigs initially utilized in these experiments, we have come to use human guinea pigs as the subjects of experiments. Despite the possible advances that this attitude may have provided within the scientific domain, it is impossible not to question the statute of human life in these procedures.

Within the field of politics, there have been many transformations from which the sciences have begun to perform a determining role. These have gone from anatomopolitics that were grounded in the discipline of bodies and aimed at increased industrialized production, to biopolitics that were grounded in control over life and aimed at producing subjective actions that are more attuned to the postindustrial way of life. For such life, it is no longer of interest to "cause to live or die" but, fundamentally, "to cause to survive", thus producing what 
Giorgio Agamben ${ }^{1}$ called "bare life". Before discussing these questions more attentively, it is emphasized that this does not mean that all workers in the more populous classes of contemporary life have been affected indiscriminately by biopower strategies. To detail the diversity of action of its mechanisms, it would be necessary to consider at length the innumerable sociopolitical, economic and cultural differences between different populations, which was not the objective of the present paper. In passing from power to biopower, the ethical questions embedded in scientific practices have ended up becoming increasingly prominent. For example, what can the basis be for a bioethical approach that not only protects human beings from pure and simple perverse utilization as instruments, but also poses the question of the statute of vulnerability of some lives? What is the statute of life in the light of the sovereignty exercised by biopower? Or, furthermore, at the presentday frontiers of biopolitics, could there be some more worthy lives that enjoy the advances of science and other lives considered to be of lower value, which would serve mainly as guinea pigs for scientific experiments? These are just some of the questions than cannot remain without replies or that, at the very least, demand more attentive and rigorous questioning.

\section{QUESTION OF VULNERABILITY AND GETTING HURT}

In a paper with the title "Bioethics, vulnerability and protection", ${ }^{20}$ Ruth Macklin posed the following question: "what makes individuals, groups or countries vulnerable?" According to the definition of the international ethical guidelines for biomedical research, revised by the Council for International Organizations of Medical Sciences, * "vulnerable people are those people who are relatively or absolutely incapable of protecting their own interests. In a more formal manner, they may have insufficient power, intelligence, education, resources, strength or other attributes that are necessary for protecting their interests" (p. 60) ${ }^{20} \mathrm{In}$ the light of this definition, ${ }^{20}$ the principal characteristic of vulnerability expressed by this guideline is "limited capacity or freedom", thus showing that specific groups could be considered vulnerable, as follows:

"These include subordinate members of hierarchical groups such as soldiers or students; elderly people with dementia who are living in old people's homes; people receiving social security or care benefits; other poor unemployed people; patients in emergency rooms; some minority ethnic and racial groups; homeless, nomadic and displaced people or refugees; prisoners; and mem- bers of communities that have no knowledge of modern medical concepts" (our emphasis) (p. 61).

Forming part of a critical tendency in the debate on the ethics of research on human beings, Macklin intended to turn bioethics into a political instrument that would ensure protection and, consequently, non-exploitation of vulnerable individuals. Her articles and texts record specific situations that cause reflection on this problem.

However, with the aim of better discussion of the question posed above, it is noted that her definition of vulnerability relates not only to a group of people momentarily incapable of exercising their freedom because of physical contingencies or because of the "natural" consequences of the course of life, but also to another group that also shows itself to be incapable, but because of "social" and "political" consequences. Thus, going back to the definition of the Council for International Organizations of Medical Sciences, it can be seen that what partially characterized this second group is a lack of definition of the statute of their citizenship.

Further considering other problems present in this definition, some authors have proposed to make a distinction between the concept of vulnerability and the concept of susceptibility or getting hurt. ${ }^{19,23}$ Kottow $^{19}$ argued that vulnerability was an anthropological attribute of all human beings, because of the simple fact of being alive, while susceptibility was a disadvantage that arose in some social groups or individuals. Likewise, Schramm** proposed that, although potentially or theoretically vulnerable, not all people actually get hurt. In this respect, it is essential for contemporaneous bioethics to distinguish "mere vulnerability from effectively getting hurt". This shift allows the idea of equality and justice in the globalized world to be rethought, since it accepts a situation of asymmetry. In this sense, individuals and populations are momentarily excluded from the rule of law, living in an indeterminate zone in which their freedom is diminished and their lives lose value.

Thus, the debate about vulnerability, susceptibility and getting hurt becomes the epicenter of reflections on contemporaneous bioethics, which can, however, only be elucidated by putting it into its biopolitical context. With this objective, the discussion moves on to the subject of contemporary biopolitics so that, from this, the effective reach of biopolitics across the topic of bioethics can be better assessed.

\footnotetext{
* World Health Organization, Council for International Organizations of Medical Sciences. International ethical guidelines for biomedical research involving human subjects. Geneva; 2002. Available at: http://www.cioms.ch/frame_guidelines_nov_2002.htm [Accessed on Jan 30, 2006]

** Schramm FR. A Saúde é um direito ou um dever? Considerações sobre vulnerabilidade, vulneração, proteção, biopolítica e hospitalidade. Draft text, 10p.
} 


\section{BIOPOLITICS IN FOUCAULT AND AGAMBEN}

Michel Foucault situated biopolitics within the picture of a broader strategy that he called biopower. His fundamental hypothesis was that, under a regime of sovereignty, the subject owed his life and death to the will of the sovereign: "it is because the sovereign can kill that he exercises his right over life", ${ }_{14}^{4}($ p. 287). Under these conditions, power is a mechanism for removal and usurpation, i.e. a negative power over life. Differently, in the classical era, power ceased to be based predominantly on removal and appropriation, so as to function on the basis of incitement and surveillance. The sovereign started to produce, intensify and order forces more than limiting or destroying them. This is the point at which the classical passage of power to biopower as proposed by Foucault can be situated: "from causing to die and letting live [sovereignty]" power became "causing to live and letting die [biopower/biopolitics]" (Foucault, ${ }^{15}$ p.181).

This "causing to live" that characterizes biopower is based on two specific technologies. This first of these, which was created in the seventeenth and eighteenth centuries, consists of techniques that are essentially centered on the individual body and characterized by procedures that ensure its spatial distribution and the organization of its visibility (techniques for rationalization and economy that are destined to increase the useful force). The combination of these techniques comprises a given discipline. In the course of the eighteenth century, another technology of power emerged, which did not exclude the first technology but, in addition to making the body whole, was directed essentially towards managing life (births, deaths, health and longevity). Thus, the anatomopolitics of the body became the biopolitics of life.

According to Giorgio Agamben, ${ }^{3}$ from this hypothesis, Foucault placed biopolitics in a problem-setting relationship between life and history, or between life and politics.

“... What could be called the "threshold of biological modernity' of a society is situated at the moment when the species becomes a being that puts its own political strategies into play. For thousands of years, man remained what he was for Aristotle: a living animal and, in addition to this, capable of political existence; modern man is an animal whose life of a living being is in question through his politics" (Foucault, ${ }^{15}$ p.134).

But, more specifically, what would this perception of life through politics or this total politicization of life consist of?

In working on the question of power, Foucault did not put the legal institutional approach in a privileged position, but sought to analyze the way in which power penetrates into bodies and produces subjective actions. For this reason, his investigations were aimed fundamentally towards the political techniques and the technologies of the individual. However, even though favoring what is conventionally called micropolitics, Foucault stated that the modern Western state brings together subjective individuation techniques and objective totalization procedures in unprecedented proportions. He referred to a "double link constituted by individuation and simultaneous totalization of the structures of power"15 (p. 229-232).

Nonetheless, also according to Agamben, ${ }^{3}$ the point at which these two aspects of power converge was not clarified by Foucault's thinking, and it remained as a "concealed point" or an "indeterminate zone". In these terms, any approach towards this would require superposition of the two forms of power described above: patchwork between the sovereignty and biopolitics models.

Going back to the Greek distinction between zoe, the simple fact of living - which is common to all living beings (animals, man or gods) - and bios (the way of living that is particular to an individual or group), Agamben emphasized that when Plato and Aristotle theorized about life, they did not use the term zoe. This was because what was at issue was not simple natural life but only qualified life, i.e. the particular way of life. The polis did not include natural life, which remained as mere reproductive life within the sphere of the oikos (home). Agamben then referred to a passage by Aristotle in Politika, which is considered to be fundamental to the Western political tradition. In this, the philosopher defines the "goal of the perfect community" and contrasted the simple fact of living with life that was politically qualified, "born with a view to living, but existing essentially with a view to living well" (p. 11). Considering this contrast that Aristotle made, it can be stated that, in ancient times, zoe was not picked up by the devices of politics. As seen earlier, on the basis of this definition, Foucault showed how, at the threshold of the Modern Age, natural life started to be included in the mechanisms of state power, and politics became transformed into biopolitics (idem).

On the other hand, Agamben ${ }^{3}$ referred to the fact that, in The Human Condition at the end of the 1950s, Hannah Arendt, ${ }^{6}$ had already analyzed the process that led working men's lives to occupy the center of political power in the modern era. ${ }^{6}$ According to Arendt, this primacy of natural life over political action would explain the transformation and decadence of the public space, thus causing Western democracies to be easily transformed into totalitarian regimes. From these hypotheses, Agamben stated that "the entry of the zoe into the sphere of the polis, the politicization of bare life as such, constitutes the decisive event in the modern era, 
which signals a radical transformation of the politicalphilosophical categories of classical thinking"s (p. 12). Only reflection that interrogates the relationship between bare life and politics would enable comprehension of the production of the indeterminate zones that form part of the scenario of modern life. This reasoning means that this study ${ }^{3}$ relates to the totalitarian states of the twentieth century, in which a biopolitical body was constituted as the original contribution of the sovereign power.

\section{STATES OF EXCEPTION AND PRECARIOUS LIFE}

For Agamben, the state of exception is the device through which the law forms part of life. The main reference to this paradoxical phenomenon is the possibility, invoked by modern totalitarianism, of starting a "legal civil war", ${ }^{5}$ in which the Nazi State was the biggest example. Through the "Decree for the protection of the people and State", proclaimed in February 1933, Hitler suspended the articles of the Weimar constitution, thereby enabling the elimination of the lives of not only political adversaries but also entire categories of citizens. Since that time, the creation of a permanent state of emergency has become one of the political practices of contemporaneous "democratic" states (Agamben, ${ }^{2}$ 2004 p.13). This practice of the state of exception has made it possible to annul the individual's legal statute, thus creating a legally nameless being.

One of the best contemporary examples of this situation is the "indefinite detention" of the Taliban captured in Afghanistan, proclaimed by George Bush. These people are considered to be neither prisoners nor under accusation: they are "detained" and are subject to "pure sovereignty in reality" and deprived of any possibility of exercising their citizen's rights. Partially adopting Agamben's hypotheses, Judith Butler' analyzed the precarious condition of the detainees at Guantánamo, and showed that they are exactly in the "indeterminate zone" mentioned earlier. The detainees are subject only to the decree proclaimed by the Department of Defense of the United States government, on March 21, 2002. This, in the name of a security alert, suspended the national and international laws. These individuals, described as "potential terrorists", remain in a state of eternal detention without the right to any judgment.

To go into the topic more deeply, Butler resorted to the same argument as proposed by Agamben. In this, taking Foucault's hypotheses as the reference, sovereignty and biopolitics are perhaps not mutually exclusive regimes. On the contrary, biopolitics exercised by governmentality would allow administration of regulations to be established bureaucratically, and would accept the exercising of sovereign power through the state of exception. With regard to suspension of the authority of the law, Butler showed that "the relative loss of sovereignty that results from the present predominance of governmentality is compensated by the reemergence of sovereignty within the field of governmentality" (Butler, ${ }^{9}$ p. 85).

From Nazism to Guantánamo, the way in which democratic regimes in the West have been transformed can be traced out. The progressive expansion of executive power has made it possible for the state of exception to emerge as a technique for governing. The proclamation of a state of exception is increasingly seen not only as a security measure but also as the defense of "democracy" (p. 32-33). However, according to Walter Benjamin, ${ }^{8}$ the problem of the state of exception presents evident analogies with the question of the right to resistance. He showed that the resistance should appropriate the exception as an instrument in the antifascist struggle, thereby subverting its legal-political presuppositions. Under these conditions, he raised the hypothesis that absolute profanation would coincide with full consecration:

"The tradition of the oppressed teaches us that the 'state of exception' in which we live henceforth becomes the rule. We need to reach a conceptualization of history that corresponds to this situation. We will then have our task in front of our eyes: to cause the state of exception to become effective; this will reinforce our position in the struggle against fascism" (Benjamin, ${ }^{8}$ 1996: 226).

The indication that Benjamin seems to leave in this passage is that one of the main political tasks of the resistance is the appropriation - by means of a type of profanation of what cannot be profaned (Agamben, ${ }^{4}$ 2005) - of the possibilities for struggling against fascism, which are caught up by the devices of power that are instituted by the state of exception.

Inspired by Benjamin's observation, Agamben made an exhaustive analysis of the legal traditions and argued that there was a debate between those who tried to include the state of exception within the domain of the legal system and those who considered it to be outside it. It should be remembered that the relationship between exception and sovereignty was initially established by Carl Schmitt in his book Political Theology. According to Schmitt, the sovereign is the one who decides about the state of exception (Taubes, ${ }^{25}$ 1999). Although there has been widespread comment about this phrase, Agamben stated that there was no theory for the state of exception in public law. He asked: if the purpose of the state of exception was to suspend the legal system, how could this be understood within the legal order? Or, on the other hand, if the state of exception was only a situation of reality that was foreign to or contrary to the law, how would it be possible for the legal system to present a gap precisely in this situation? (Agamben, $\mathrm{p}$. 39). In the latter case, it would not just be a topological question - inside or outside of the legal system - but an undifferentiated zone in which inside and outside are 
not mutually exclusive given that they are reciprocally indeterminate. The modern state of exception would therefore be an attempt within the legal system to include its own exception, thereby creating a gray zone in which event and law coincide (p. 43).

In the theories analyzed by Agamben, there are various examples of overlapping between the acts of the executive and legislative powers. However, the most important point in this debate is to comprehend the problem posed in applying the law. Referring to the lecture given by Derrida" "Force of Law: the mystical basis for authority", what is in question is the possibility of isolating the "force of law in relation to the law". The state of exception would be a "state of law" in which the law is in force, but does not have the strength to be applied. In this state of exception, on the other hand, acts that do not have the value of law acquire their "force". In such cases, the "force of law" floats as an element of legal indeterminacy: a force of law without law; a lawless space at the heart of the law.

In this respect, Foucault's hypothesis needs to be supplemented. Now, this is not just the inclusion of the zoe in the polis, i.e. the full inclusion of life in the devices of politics. Considering that the exception is increasingly becoming the rule, life is starting to coincide exactly with the political space, in which exclusion and inclusion, bios and zoe, and law and event come to inhabit a zone of inexorable indeterminacy. It is thus that life becomes bare life.

\section{PRODUCTION OF BARE LIFE IN THE MODERN ERA}

Taking the reference point of the discussion about the state of exception within the sphere of the law and the consequent construction of theories about the limit of human action that is expressed through exercising sovereignty, Agamben aimed to comprehend what statute life would have if it was imprisoned by and abandoned to sovereign decision. For this, he appropriated the notion of sacredness, which, outside of the domains of penal law and sacrifice, is at the origin of the political idea: "sovereign refers to the sphere in which one can kill without committing murder and without celebrating a sacrifice, and sacred, i.e. capable of being killed but not sacrificed, refers to the life that was captured in this sphere" (Agamben, ${ }^{3}$ p. 91). Sacred life or bare life would, in these terms, be the life the constituted the "primary content of the sovereign power", thus expressing the derived nature of the subjection of life to a power of death. Neither bios nor zoe, sacred life thus becomes a gray zone.
In comprehending politics in terms of a social contract and not as a sovereign bando, * Agamben considered that modern democracy had become incapable of thinking of non-state politics. Differently from the modern representation of politics as citizens' rights, freedom and the social contract, in sovereign power the political space is fundamentally the space of bare life. Thus, what had been banned ended up separated from social life, and it is this operation of inclusive exclusion that integrates contemporary biopolitics and geopolitics (Agamben, ${ }^{3}$ p. 116).

Seeking a more precise delimitation for this problem, Agamben selected the concentration camp as one of the biopolitical paradigms possible for the modern era and the "Muslim" - an Arabic term that means someone who submits unreservedly to divine will and, in the camp slang, someone who "surrenders to death" (Agamben, ${ }^{3}$ p. 64) - as an emblematic figure for bare life. According to the report by Primo Levi in the book Is this a man?, "Muslim" was the name chosen to designate an undefined being, a limiting experience of suppression of human dignity in the concentration camps. In this experience, vegetative life and political life are confused with each other, which makes the "Muslim" "the full witness" of the ethics of Auschwitz (Agamben, ${ }^{1}$ p. 57). From the testimony of the "Muslim", the camp could be considered to be the uncontestable example of the fact that the state of exception had become the rule. It was not only the place of death, but above all the stage for an experiment in which, beyond life and death, the Jew was transformed into a "Muslim".

Within a space in which the technology of death is materially achieved in a "vulgar, bureaucratic and dayby-day" manner, death and its fabrication cease to be different: both are transformed into a mere product of technical sophistication. Once again, this degradation of death today can only be comprehended by means of superposing the two models of power described by Foucault. ${ }^{14}$ The unprecedented attainment of absolutism in biopower is conjugated with the generalization of sovereign power, and biopolitics necessarily becomes confused with thanatopolitics. In this light, Agamben proposed a third formula in which the specificity of the biopolitics of the twentieth century would be grasped: "no longer causing to die, or letting live, but causing to survive" (Agamben, ${ }^{1}$ p. 108). Not life and not death, but only production of survival.

In effect, with each separation between non-human and human, new frontiers between "Muslim and man", between "vegetative life and conscious life", between "citizens and refugees" and between "qualified lives and lives without any value" are set up. In the last of

\footnotetext{
* In the author's words: "... in bando, a bandono originally means in Italian 'at the mercy of... ', and bandido means both 'excluded, banned' and 'open to all, free'... Bando is specifically the simultaneously attractive and repulsive force that links the two poles of the sovereign exception: bare life and power; sacred man and the sovereign" (Agamben, ${ }^{3}$ p.117).
} 
these cases, the specific situation of some developing countries can be highlighted, in which the disqualification of some lives is blatantly visible. Thus, the isolation of a residual life within the continuum of life can also be defined, in which survival is at the price of its degradation.

\section{"LIFE WITHOUT VALUE..."}

In modern political history, there are various examples of these biopolitical frontiers. Among others, Agamben mentions the separation between humanitarian and political frontiers, the definition of the concept of death, the waiting areas in airports, and also certain parts of the peripheries of cities. However, for the present study, Agamben's philosophical reflections on the research on human beings conducted within the Nazi eugenic projects are highlighted. This research gave rise to the first declaration on ethics in research, in the Nuremberg Code (1947).

The sovereign, i.e. the one who decides on the state of exception, also decides on life than can be dead without committing murder. ${ }^{3}$ This was one of the political stances of the German National Socialist State, which took to an extreme the possibility of metamorphosis of life, through making it possible to kill it and at the same time making it impossible to sacrifice. Thus, the sovereign decides the point at which life may become politically irrelevant, and in this sense without value, i.e. subject only to the pure exercising of a technique. In this type of practice, politics and medicine mix, thereby radicalizing the biopolitical principle of sovereignty to its maximum (Agamben, ${ }^{3} \mathrm{p}$. 149-50). There is nothing more shocking than the records of the medical files of the Versuchspersonen (VP), the so-called "human guinea pigs" in the concentration camps. These beings, deprived of all the rights and attributes that are customarily those of humans, existed only as biological life while awaiting their execution, and were subjected to a wide diversity of types of scientific experiments. One example:

"On May 15, 1941, Dr. Roscher, who for some time had been conducting research on lifesaving at high altitude, wrote to Himmler to ask him whether, given the importance that his experiments had taken on for the lives of German aviators and the mortal risk that they bore for the $V P$ (Versuchspersonen, human guinea pigs), and considering, on the other hand, that the experiments could not be gainfully conducted on animals, it would be possible to have "two or three professional delinquents" available to him in order to proceed with the experiments" (Agamben, ${ }^{3}$ p. 161).

Considering the terms of the above correspondence, it seems that on the biopolitical level characteristic of the modern era, doctors and scientists move in a kind of no man's land that previously only the sovereign could enter (Agamben, ${ }^{3}$ p. 16).

Despite the progress of the Western democracies, which cannot be compared in any way to the Nazi State, the twentieth century was marked by successive denouncements of research on human beings, which at least until the beginning of the 1970s was still being performed without much ethical commitment. One of the most frequently mentioned examples is the Tuskegge Study on syphilis, which was carried out in Alabama, in the United States, from 1932 to 1972.* In this, 400 black men who were contaminated with this disease remained untreated so that the natural course of the disease could be observed, even though the cure using penicillin had been discovered at the end of the 1920s. After 40 years of experiments on the participants, only 74 were still alive at the end of the project. Another example that has given rise to much comment is the article "Ethics and Clinical Resarch", published by Henry Beecher ${ }^{7}$ in 1966. In this study, the author selected 50 reports on ethically questionable research on human beings that had been published in scientific journals, from which he revealed 22 examples conducted among patients in charity hospitals, children, mentally deficient adults, prisoners and newborns. These individuals had not been given enough information or explanations about the objective or about the fact that research was being conducted, thereby making them mere experimental objects (Diniz \& Corrêa ${ }^{13}{ }^{2001)}$.

In this debate, bioethics has emerged as an academic and applied practical discipline, thus constituting not only an instrument for reflecting on the advances of technology and biomedicine, but also a form of protection for the human beings involved in such research.

\section{EMERGENCE OF BIOETHICS}

Several authors have placed the emergence of bioethics at the start of the 1970s. One of the most significant historical markers in the genealogy of the discipline was the publication of the book "Bioethics: bridge to the future", by Van Rensselaer Potter ${ }^{21}$ (1971). However, André Hellegers, ${ }^{13}$ at the University of Georgetown, was the first to institute the term, with the objective of designating a new field of activity, which gave rise to the so-called principlist school (Diniz \& Guilhem, ${ }^{12}$ p.11). Within this school, bioethical reflection was systematized by drawing up four principles: 1) autonomy, which starts from the presupposition that, to exercise freedom, an individual needs to be autonomous, i.e. in conducting biomedicine, all the participants must give their voluntary informed consent, both for therapeutic

\footnotetext{
* Gostin, L, editor. Public health law and ethics. Los Angeles. University of California Press; 2002. In: Selgelid²4 (2005).
} 
projects and for research to be conducted; 2) beneficence, presupposing that all medical acts have the aim of doing good; 3 ) non-malevolence, based on the deontological principle that causing damage must be avoided as much as possible; and 4) fairness (Childress \& Beauchamp, ${ }^{10}$ 1994).

These ethical principles are grounded in moral discussion coming from the interaction between individuals, with the basic presupposition of both civic equality between citizens and politics of reciprocity of the social contract. The emphasis on individual autonomy - a direct influence of Anglo-Saxon ethics - establishes the priority of reflecting on doctor-patient or researchersubject relationships, which remain much below the discussions relating to the field of public health and social inequality.

However, starting in the 1990 s, new theories have emerged and have begun to pose questions regarding the hegemony of the principlist theory. Economic globalization, problems of social exclusion experienced in peripheral countries, lack of access to scientifictechnological development among vulnerable groups and inequality of access to consumer goods essential for survival among poor people have in effect started to form part of the reflections of researchers engaged in transformative bioethics (Garrafa, ${ }^{16}$ p.34). In this respect, ethics based on universal principles cannot be applied or simply incorporated within a context of inequality. It is also important to develop reflections that allow the complexities of Third World societies to be taken on board $\left(\right.$ Kottow $\left.^{18}\right)$.

Thus, according to Schramm, ${ }^{22}$ even if it is considered that contemporary bioethics is crossed by tension that is produced by two distinct paradigms, it is fundamental to understand today's biopolitical context, or else the network of complexity constituted by the challenges of biotechnology will not be attained. These paradigms are: the ethical paradigm of "sacredness of life", which is strongly influenced by religious doctrine based on the inviolability of human life, and the ethical paradigm of "quality of life", which is characteristic of secular and lay bioethics. By defining this concept as an integrated interdisciplinary set of theories, technological-scientific skills and industrial applications (biotechnology), Schramm showed that:

"... in the debate between the "bioethics of sacredness of life" and the "bioethics of quality of life, there is an issue that was detected both in Foucault's writings and those of Agamben and Derrida..., about which there has been little thought. [This] relates to the human condition that is experienced and suffered, and we are called on to think about life before giving it adjectives in terms of "sacredness" or "quality", with regard to the matters of "frailty", "forsakenness", "bareness" and "mortality" (Schramm, ${ }^{22}$ p.21).

There have been advances over recent decades, particularly through the consensus regarding the Declaration of Helsinki. This represented the consolidation of the ethical precepts already instituted by the Nuremberg Code, and it has been transformed into the biggest reference point for regulating ethics in research for the medical-scientific community in various countries. Despite this, one of the principal debates conducted in bioethics forums today relates precisely to the topic of devaluation of the lives of individuals who, because they are in a badly hurt sociocultural situation, have ended up treated as mere objects of experimental research. This once again refers to the scenario of the modern era in which the sovereign power exercised by technique has transformed life into bare life.

\section{PRESENT DEBATE ON RESEARCH USING HUMAN BEINGS}

Much has already been said about the proposal to modify the Declaration of Helsinki, which was suggested by the World Medical Association in 1999, concerning the questions raised by the debate on standards of treatment and clinical trials (Diniz \& Corrêa, ${ }^{13}$ 2001; Garrafa \& Prado, ${ }^{16}$ 2001). This discussion originated in analyses of studies on prophylactic therapy aimed at preventing HIV transmission from mother to child, with placebo controls, which were sponsored by various international institutions and carried out in certain "developing" countries, particularly in Africa. It is well known that, since 1994, zidovudine (AZT) has been in use for reducing the risks of HIV transmission from mother to child, and this is a standard treatment for such cases. However, those experiments involved tests against placebo, which meant that at least half of the population investigated remained untreated (Selgelid, ${ }^{24}$ 2005). The first criticisms of that research were made by Lurie \& Wolfe, ${ }^{*}$ since those procedures violated one of the principal articles of the Declaration of Helsinki regarding research using human beings. According to this article, "in medical studies, all patients - including those in the control group, if any - must be guaranteed access to the best diagnosis and best proven therapeutic method".** This resolution had the aim of ensuring that research participants would get the best medical treatment available. However, even in the light of these criticisms, the researchers and the funders of this type of research did not at first draw back in any way. On the contrary, a proposal for modifying this declaration

\footnotetext{
* Lurie P, Wolfe S. Unethical trials of interventions to reduce perinatal transmission of the human immunodeficiency virus in developing countries. N Engl J Med. 1997;337(12):853-6. (apud Diniz \& Corrêa ${ }^{13}$ )

** Helsinki (1964, reformulated 1975,1983,1989,1996 and 2000), from the World Medical Association. (apud Selgelid ${ }^{24}$ )
} 
was formulated, which puts at risk the advances so far achieved. Thus, in 1999, the World Medical Association proposed a modification for the aforementioned article, as follows:

"in any protocol for biomedical research, all patients, including those in the control group, if any, must be assured that they will not be denied access to the best diagnosis and/or proven prophylactic or therapeutic method that otherwise would be available to such patients (our emphasis)"( Selgelid, ${ }^{24}$ 2005: 117).

What can be gathered from this new version is that the local standard for treatment (which in the case of African countries means no treatment) would serve as an ethically acceptable control instrument. This means, in the final analysis, that these people's lives are transformed into mere research objects that can be manipulated for investigative purposes. More recently, in 2000, taking into account the reaction from the international community, a new formulation recommends that:

“...in any medical study, all patients - including those in the control group, if any - must be assured of a prophylactic diagnosis and a therapeutic method of proven efficacy..."24 (p. 117)

In the light of the ambiguity of this last proposal, the Declaration of Helsinki needs to be discussed once again, and it may even be altered again (Greco, ${ }^{17} 2003$ p. 260).

Summarizing, this rapid explanation allows the following conclusion to be reached: a double standard for research is proposed, or furthermore, double standards in the ethics for research using human beings: one for developed countries and the other for "developing" countries. This again requires questioning with regard to "differentiated valuing" of people's lives that promotes the establishment of biopolitical frontiers between "politically relevant" lives and lives of "lower value".

\section{FOR POLITICS OF LIFE}

As shown, if the devices of power in modern democracies conjugate biopolitical strategies with the emergence of the force of the sovereign power that transforms life into bare life, the fact is that bioethics ought to be an instrument for protecting people who have been hurt. In these terms, and recovering the significance of the Greek word "ethos" - which also has the senses of "aid", "watching over" and "shelter" - Schramm \& Kottow $^{23}$ (2001) proposed bioethics for protection. This was intended to be more than a descriptive-normative tool, and had the objective of mediating in conflicts of interest and values. Furthermore, its aim was, "in perhaps a deeper and more primordial manner, to constitute protection against the threats of "bare life" (Schramm, ${ }^{22}$ p. 24).

It is considered to be important to accentuate this shift or bending, which, going beyond the territory of the rule of law, causes bioethics to also be able to penetrate this gap, this no man's land, this undifferentiated zone, in which sovereignty and technique mix, thereby making these frontiers profane and posing questions about the very definitions of vulnerability and getting hurt, from less biopolitics. Precariousness and a certain insufficiency of life need to be considered to be highly relevant conditions in a mode of singular creation of subjection, instead of being used as tools in a process of producing subjective states that are only aimed at maintaining the dominant "status quo" of biopolitical power.

It may happen that bioethics comes to fill this gap and may also return to life what is inherent to it. As Agamben showed:

"the body of the sacred man and bare life constitute the force and, at the same time, the intimate contradiction of modern democracy: it does not cause sacred life to be abolished, but it tears it into pieces and spreads it in each individual body, thus making life the bet in a game of political conflict. The body is a bifrontal being that has both subjection to the sovereign power and individual freedoms (Agamben ${ }^{3}$ p.130). 


\section{REFERENCES}

1. Agamben G. Ce qui reste d'Auschwitz. Paris: Rivages; 1998.

2. Aganben G. Estado de exceção. São Paulo: Boitempo; 2004.

3. Aganben G. Homo Sacer. O Poder soberano e a vida nua. Belo Horizonte: UFMG; 2004.

4. Aganben G. Profanation. Paris: Bibliothéque Rivages; 2005.

5. Arán M. Soberanias, da guerra à comunidade. In: Arán M, organizador. Soberanias. Rio de Janeiro: ContraCapa; 2003. p.9-14.

6. Arendt H. A condição humana. Rio de Janeiro: Forense Universitária; 1989.

7. Beecher HK. Ethics and clinical research. N Engl J Med. 1966;274(24):1354-60.

8. Benjamin W. Magia e técnica, arte e política. São Paulo: Brasiliense; 1994.

9. Butler J. Vie précaire. Les pouvoirs du deuil et de la violence après le 11 septembre 2001. Paris: Èditions Amsterdam; 2005.

10. Childress F, Beauchamp TL. Princípios de Ética Biomédica. São Paulo: Loyola; 2002.

11. Derrida J. Force de loi. Paris: Galilée; 1994.

12. Diniz D, Guilhem D. O que é Bioética. São Paulo: Brasiliense; 2002. p.10-20.

13. Diniz D, Corrêa M. Declaração de Helsinki: relativismo e vulnerabilidade. Cad Saude Publica. $2001 ; 17(3): 679-88$.

14. Foucault M. Em defesa da sociedade. São Paulo: Martins Fontes; 2002.

15. Foucault M. História da sexualidade I. A vontade de saber. Rio de Janeiro: Graal; 1993.
16. Garrafa V, Prado M. Mudanças na Declaração de Helsinki: fundamentalismo econômico, imperialismo ético e controle social. Cad Saude Publica. $2001 ; 17(6): 1489-96$.

17. Greco DB. Poder e injustiça na pesquisa com seres humanos. In: Garrafa V, Pessini L, organizadores. Bioética, poder e injustiça. São Paulo: Edições Loyola; 2003. p. 258-69.

18. Kottow M. The vulnerable and susceptible. Bioethics. $2003 ; 17(56): 460-71$

19. Kottow M. Bioética de proteção: considerações sobre o contexto latino-americano. In: Scramm FR, Rego S, Braz M, Palácios M. Bioética: riscos e proteção. Rio de Janeiro: UFRJ/FIOCRUZ; 2005. p. 29-44.

20. Macklin R. Bioética, vulnerabilidade e proteção. In: Garrafa V, Pessini L, organizadores. Bioética: poder e injustiça. São Paulo: Loyola; 2003. p. 59-70.

21. Potter VR. Bioethics: bridge to the future. New Jersey: Prentice-Hall; 1971.

22. Schramm FR. A moralidade da biotecnociência: a bioética da proteção pode dar conta do impacto real e potencial das biotecnologias sobre a vida e/ou a qualidade de vida das pessoas humanas? In: Schramm FR, Rego S, Braz M, Palácios M, organizadores. Bioética, riscos e proteção. Rio de Janeiro: UFRJ/ Fiocruz; 2005. p. 15-28.

23. Schramm FR, Kottow M. Principios bioéticos en salud pública: limitaciones y propuestas. Cad Saude Publica. 2001;17(4):949-56.

24. Selgelid M. Padrões de tratamento e ensaios clínicos. In: Diniz D, Gulhem D, Schuklenk U, organizadores. Ética na Pesquisa: experiência de treinamento em países sul-africanos. Brasília: Letras Livres; 2005. p. 105- 28.

25. Taubes J. La théoogie politique de Paul: Schmitt, Benjamín, Nietzsche et Freud. Paris: Seuil; 1999. 